\title{
Health Returns to Birth Weight: Evidence from Developing Countries
}

\author{
Vaibhav Keshav \\ University of Illinois Urbana Champagne
}

\begin{abstract}
This paper explores the effect of birth weight on a series of anthropometric outcomes among children. We use a panel of individual-level data from 39 developing countries covering the years 1999-2018 and attempt to solve the Endogeneity using mother fixed effect and twin fixed-effect strategies. The results suggest that improvements in birth weight result in statistically and economically significant improvements in children's anthropometric outcomes. An additional 100 grams birth weight is associated with a 0.43 and 0.25 units increase in weight for age percentile and height for age percentile, respectively. The links are stronger among low educated mothers and poorer households. The observed protective effect of birth weight on infant mortality suggests that the true effects of birth weight on children's outcomes are larger and that the estimated effects probably understate the true effects.
\end{abstract}

Keywords: Health, Fetal Origin Hypothesis, Children Anthropometry, Height for Age, Weight for Age, Birth Weight, Twin Fixed Effect

JEL Codes: I15, P36, J13, D10

\section{Introduction}

It is well established that health endowment at birth can affect health outcomes later in life. Fetal Origin Hypothesis provides a theory to explain the link between the antenatal environment and health outcomes later in life. Based on the theory, while the genetic variations among humans are very minuscule (Witherspoon et al., 2007) the epigenetic programming variations are relatively large. An Epigenome is a multitude of chemical compounds that are attached to the DNA and turns off some genes as a response to environmental stressors. The shocks during prenatal development could trigger these changes and program Epigenome to turn off some genomes related to growth with the sole purpose of survival of the fetus. This results in below-normal growth in tissues, brain cells, and other organs. This deficiency in the growth of certain organs is reflected in lower birth weight and conceals its importance later in life (Almond and Currie, 2011). To empirically investigate this 
link, a strand of literature in economics and health documented the causal effects of birth outcomes, and specifically birth weight, on long term mortalities due to respiratory disorders, neurodevelopmental disabilities, and hypertension (Behrman et al., 2007), child mortality (Lau et al., 2013; McCormick, 1985), and other socioeconomic outcomes such as education and earnings in adulthood (Behrman and Rosenzweig, 2004; Bharadwaj et al., 2018; Conley et al., 2006; Figlio et al., 2014; Maruyama and Heinesen, 2020; Miller et al., 2005).

A small branch within this literature focuses on the fetal origins of anthropometric outcomes of children. For instance, Bacallao et al. (1996) use longitudinal panel data and document that children with higher birth weight are more likely to have higher height during different ages. The birth weight is also a good predictor of the onset of the pubertal maturation process. These studies usually point to correlational links and fail to offer a causal path (Bacallao et al., 1996; Sorensen et al., 1999) and mostly use data from developed countries (Datta Gupta et al., 2013). This study aims to fill this gap in the literature by using data from developing countries and applying a twin fixed-effect strategy to solve the Endogeneity issues.

Using individual-level panel data from 39 developing countries over the years 19992018 and applying various econometric techniques, this paper explores the link between birth weight, as an important measure of health at birth, and children's standardized anthropometric outcomes including weight for age, weight for height, and height for age. We apply OLS, mother fixed effect, and twin fixed-effect models and find that an increase of 100 grams in birth weight is associated with $0.35,0.43$, and 0.25 percentile units rise in weight for height, weight for age, and height for age, respectively. These changes are equivalent to $1,1.8$, and a 0.9 percent rise from the mean of their respective variables over the sample period. Besides, we show the heterogeneity of these associations based on the mother's education and the household wealth quantiles. We find that the links are stronger for low educated mothers and persists with a stronger momentum among children in poor families.

The results of this paper have important implications for governments and policymakers. Since the anthropometric outcomes and specifically height are among the important determinants of labor market success and lifetime earnings (Brinkman et al., 1988; Deaton and Arora, 2009; Meyer and Selmer, 1999), exploring their fetal origins offer an effective long-run policy channel to promote labor outcomes. In addition, the results imply that there are externalities for health policies towards pregnant mothers that go beyond the health of infants and mothers and could affect the health of children several years later.

The contribution of the current study to the literature is twofold. First, on the contrary to the ongoing literature, we document a causal path between birth weight and medium-run outcomes in the case of developing countries. Second, it adds to the 
literature of the Fetal Development Hypothesis by providing evidence of health endowment at birth on children's anthropometric outcomes.

The rest of the paper is organized as follows: Section 0 provides a brief review of the literature. In section 0 we discuss the data source and the final sample. Section 0 introduces the econometric methods implemented in the study. In sections Error! Reference source not found. and Error! Reference source not found. we report and discuss the main results and heterogeneity of the effects across sub-samples. Section Error! Reference source not found. explores one potential source of sample selection bias. Finally, we depart some concluding remarks in section Error! Reference source not found..

\section{A Brief Literature review}

A small strand of literature in public health and economics investigates the association between birth outcomes and adult height. For instance, Sorensen et al. (1999) use a longitudinal panel of Danish men and find that birth length is a strong predictor of adult height. The association still holds even after controlling for birth weight and other socioeconomic confounding factors. Gupta et al. (2013) show that the link between low birth weight and physical growth among children becomes weaker by age and that it is stronger for children in the very low birth weight category.

Focusing on anthropometric outcomes is essential mainly due to the hidden benefits associated with improvements in these outcomes. Deaton and Arora (2009) show that taller people in the US population are on average happier, are more likely to have positive emotions, are less likely to suffer from sadness, are less probable to have negative mental experiences, and have higher education and income. The relationship between height and income is also supported in other studies (Brinkman et al., 1988; Meyer and Selmer, 1999).

Birth weight also has long-run impacts on a wide range of labor market outcomes. For instance, Behrman and Rosenzweig (2004) apply a twin fixed-effect strategy to explore the effect of birth weight during adulthood. They find consistent evidence that higher birth weight is associated with higher educational levels and higher earnings. If the birth weight of the bottom half of the US population reaches that mean of the US birth weight (an increase of roughly 480 grams), their average earnings would go up by about 6 percent. Using longitudinal data and applying an instrumental variable strategy, Maruyama and Heinesen (2020) explore the effect of birth weight on medium-run health outcomes and long-run non-health outcomes. They find that a 10 percent rise in birth weight is associated with about 13.7 fewer infant death per 1,000 births. However, they do not find any evidence for the long-run effects on other outcomes such as test scores. Royer (2009) exploits the plausibly random variations in birth weight among twins and shows that birth weight has small but explanatory power for later pregnancy complications and the birth weight of the next generation. 
(Almond et al., 2005) explore the hospital discharge costs and infant mortality rates associated with low birth weight. They find that the average hospital discharge costs of having a low birth weight infant in excess of the costs of having a normal birth weight infant add up to roughly $\$ 8,654$ in 2000 dollars.

The environmental shocks during prenatal development could, in turn, affect birth outcomes including birth weight. Hoynes, Miller, and Simon (2015) explore the effects of the changes in the Earned Income Tax Credit payments birth outcomes. The cash transfers created a sizeable and permanent shock to households' income. The increased income encouraged health care spending including prenatal care and private health insurance. They find that a $\$ 1,000$ treatment-on-the-treated increase in income is associated with 6.4 grams higher birth weight and about 2-3 percent reduction in low birth weight. Cole and Currie (1993) explore the effect of cash transfers from Aid to Families with Dependent Children (AFDC) on infants' health outcomes and find no evidence that the program has any effect on birth weight. Noghanibehambari and Salari (2020) explore the effects of unemployment insurance generosity as a temporary shock to income and find that the payments have externality for infants' health outcomes including birth weight, low birth weight, Apgar score, and gestational age. Similar studies have explored the effects of government welfare and health programs on infants health outcomes (Almond et al., 2011; Currie and Grogger, 2002; East, 2018; Figlio et al., 2009; Ga and Feng, 2012; Hoynes et al., 2011, 2016; Kaestner and Chan Lee, 2005; Leonard and Mas, 2008; NoghaniBehambari et al., 2020b, 2020a; Noghanibehambari et al., 2020; Sonchak, 2015, 2016; Tavassoli et al., 2020; Wherry et al., 2018)

\section{Data and sample selection}

The primary source of data is a collection of Demography and Health Surveys (DHS) extracted from Heger Boyle et al. (2020). The DHS Program collects survey data from individuals across developing countries on topics such as health and demography. This program is implemented by ICF International and funded mainly by the United States Agency for International Development. The data provides a variety of information including mothers' demography, birth outcomes of children ever born, and anthropometry of their survived infants up to age 5 . To the benefit of the current study, it also reports whether the child is single, twin, triplet, etc. We remove all individuals and samples for which the essential information (e.g. birth weight, anthropometric variables, mother's demography, and birth plurality) are missing. The final sample consists of 625,485 children in 39 countries over the years 1999 2018. Table 1 shows the distribution of observations across different countries. Table 2 reports summary statistics for the full sample of children and the sample of twins. Compared to the full sample, twins have lower birth weight $(2,483$ grams versus 
3,063 grams), are more likely to die during infancy ( 3.3 percent versus 0.44 percent), and are more likely to be female (50 percent versus 48 percent). Since children observed at different ages and that the anthropometric variables are highly correlated, it is inappropriate to focus on reported weight or height. Instead, we use the ranking of children relative to their peers or relative to a reference median person. This specific median value is determined by the Centers for Disease Control and Prevention (CDC). For instance, instead of focusing on height, we use the height for age in terms of standard deviation from the reference median that is defined by CDC and reported by Heger Boyle et al. (2020).

\section{Empirical strategy}

This section discusses the econometric methods used to analyze the association between birth weight and children's health outcomes. The basic idea is to compare the outcomes of children who had higher birth weight to children with lower birth weight. In summary, we use the following OLS regressions:

$$
\begin{gathered}
y_{\text {imrbt }}=\alpha_{0}+\alpha_{1} B W_{i}+\alpha_{2} X_{m}+\zeta_{r}+\eta_{b}+\phi_{t} \\
+\epsilon_{\text {imrbt }}
\end{gathered}
$$

In this formulation, $\mathrm{y}$ is the anthropometric outcome of child i born to mother $\mathrm{m}$ who reside in sub-national region $r$ who belongs to birth cohort $b$ and observed in year $t$. BW represents the birth weight of child i. In X is included a series of mother's demographic characteristics including dummies for education, wealth, type of occupation, employment status, and the number of prenatal visits. Fixed effects for the region, birth cohort, and observation year are included in $\zeta, \eta$, and $\phi$, respectively. Finally, $\epsilon$ is a disturbance term.

The assumption is that conditional on covariates and fixed effects, the anthropometric outcomes of children with higher birth weight would have followed the same path and determined by the same influences as the anthropometric outcomes of children with lower birth weight except for the fact that their birth weight varies. However, this assumption could be violated if there are certain characteristics among mothers, such as genetic attributes or socioeconomic characteristics, that affect birth weight and also are correlated with their children's anthropometric outcomes. Although we include a set of observed demographic covariates in equation 1 we are unable to control for the unobserved features. For this reason, the estimations of $\alpha \_1$ could be biased. Assuming that those unobserved mothers' attributes that confound equation 1 are time-invariant, we can include a set of mother fixed effects and re-write the equation as the following formulation:

y_imrbt $=\alpha \_0+\alpha \_1$ BW_i $\gamma_{-} m+\zeta_{-} r+\eta_{-} b+\phi \_t+\epsilon_{-} i m r b t$

This equation takes advantage of variations in birth weight to different children of a mother. In other words, it compares the anthropometric outcomes of siblings with higher birth weight to siblings (of the same mother) with lower birth weight. The 
estimated coefficient of $\alpha \_1$ in equation 2 is biased if there are unobserved characteristics of a mother that vary by time and sibling. For instance, if the socioeconomic characteristics of a mother change during the prenatal development of one child versus the other child and affect birth outcomes in ways that are unobserved, then the estimated coefficient is biased. In a similar way, if mothers discriminate in the investment of health and wellbeing of their children in unobservable ways the coefficient will be biased, too. To solve this potential source of Endogeneity, we can restrict the sample to twins and compare the outcomes of a child in twin pair with higher birth weight to his/her lower birth weight twin. In summary, we use the following twin fixed-effect strategy:

$$
y_{-} i=\alpha \_0+\alpha \_1 \text { BW_i } i+\lambda \_i+\epsilon_{-} i
$$

Where $\lambda \_i$ is set of twin fixed effects. Since twins have the same intrauterine growth and gestational age, their birth weight variation is primarily due to their differential intake of nutrition during the antenatal period. This differential intake and intrauterine growth are assumed to be random which offers a widely used strategy to search for the effects of birth weight on later-life outcomes (Behrman and Rosenzweig, 2004; Bharadwaj et al., 2018, 2019; Black et al., 2007; Figlio et al., 2014; van den Berg et al., 2011). The assumption is that the within twin variation in birth weight, after controlling for twin fixed effect, is orthogonal to other determinants of anthropometric variables of children, i.e. $\operatorname{cov}(B W, \epsilon)=0$.

\section{Main results}

We start by reporting the results of the simple OLS model introduced in equation 1 . Table 3 shows the estimated $\alpha \_1$ in equation 1 for different outcomes in different panels and slightly adding controls and fixed effects across consecutive columns. Column 1 includes country, year, and birth cohort fixed effects. Column 2 adds to these controls by including region (sub-national district) fixed effects as well as a limited set of mothers' demographic characteristics. Column 3 also adds a region-byyear fixed effect to account for all macroeconomic and environmental features specific to a region within a country that also vary by time. A full set of mothers' socioeconomic characteristics is also included in column 3 . For instance, looking at panel A and the full specification of column 3, a 10 percent rise in birth weight (equivalent to about 306 grams) is associated with a 1.6 units rise in weight for height percentile. This increase is equivalent to a 4.4 percent rise from the mean of weight for height percentile over the sample period.

As explained in section 3 , a conventional way to look at the anthropometric values is to deflate them with respect to a reference value. We use the CDC-defined values for the reference median and implement the reported percentiles or standard deviations from the reference median as the proper measures. For instance, instead of looking at the raw value of Body Mass Index (BMI), we use the BMI standard deviation from the reference median. As reported in panel G, birth weight is positively associated 
with BMI standard deviation from the reference median. If the average birth weight of children in the bottom half of the birth weight distribution could increase to the average of the sample (an increase of roughly 446 grams), the BMI standard deviation from the reference median of children would go up by 0.11 units, equivalent to a rise of $36 \%$ from the mean of the variable.

The big picture uncovered by Table 3 is that birth weight is strongly associated with improvement in anthropometric outcomes of children. The estimated effects are quite robust in magnitude across different specifications and economically significant. All the coefficients are statistically significant at $1 \%$ level.

To account for time-invariant unobserved characteristics of mothers, we include mother fixed effects as discussed in equation 2. The results are reported in Table 4 for different outcomes in different panels. Specifications in column 1 include only mother fixed effects while column 2 also controls for the region, time, and birth cohort fixed effects. The marginal effects are quite robust with and without fixed effects. Comparing the coefficients in the full specification of column 2 with those reported in column 3 of Table 3, we can see that the marginal effects have diminished in magnitude. This fact implies that unobservable characteristics of mothers overbias the estimates. However, the reductions are only marginal and the coefficients are statistically and economically significant for all outcomes and all specifications. For example, looking at panel $\mathrm{E}$, a 10 percent rise in birth weight is associated with a 1.23 unit rise in height for age percentile in the mother fixed effect model of Table 4 compared to 1.63 unit change in Table 3.

Mothers may respond to the health of their newborn by reinforcing or compensating their health endowment. If this behavior is correlated with unobservable factors of mothers, then variations in birth weight of siblings are correlated with the error term in equation 2 and the estimated coefficients are biased. Therefore, we turn our focus to the twin fixed-effect strategy introduced in equation 3 . The results are reported in Table 5 for different outcomes across different columns. While statistically significant, the magnitude of the coefficients is smaller than those in Table 3 and Table 4. For instance, a 10 percent rise in birth weight is associated with 0.07 and 0.06 units rise in weight for age standard deviation from reference median and height for age standard deviation from reference median (columns 4 and 6). These effects are equivalent to an absolute change of 6.2 and 4.6 percent change from the mean of their respective variables. For the same shock to birth weight, the marginal effects are 0.10 and 0.09 in Table 3 and 0.09 and 0.07 in Table 4. This fact implies that the withinsibling changes in unobserved mothers' characteristics slightly overstate the true effects. However, the link between birth weight and children's anthropometric variables are statistically significant and economically meaningful. Overall, the results of this section are quite comparable and similar to other studies that investigate the medium-run effects of birth weight and specifically anthropometric 
outcomes of children (Bacallao et al., 1996; Datta Gupta et al., 2013; Sorensen et al., 1999).

\section{Heterogeneity by Education and Wealth}

Restrepo (2016) shows that low-educated mothers and specifically high school dropouts reinforce the gap between their low birth weight children and their offspring with normal birth weight by providing less investment in their human capital. On the opposite, higher educated mothers compensate for this gap by providing more investment in the human capital of their low birth weight children compared to their normal birth weight children. Therefore, one may expect heterogeneity in the results based on some observed mothers' characteristics. Table 6 shows the heterogeneity of the effects for different outcomes in different columns. As discussed in section 4, the twin strategy is the preferred model that presumably accounts for unobserved factors and Endogeneity issues. Therefore, we only show the results for the twin fixed-effect models. Each panel reports the effects of a specific sub-sample based on mothers' education and household wealth. Comparing the magnitude of the effects between panel A (low educated mothers) and panel B (high educated mothers), one can observe that the link between birth weight and children's health outcomes are larger among low educated mothers. In line with the findings of Restrepo (2016), the results suggest that high educated mothers compensate for the low health endowment of their children.

Panels C and D of Table 6 report the marginal effects for poor and middle-rich families, respectively. The link between health endowment at birth and children's health outcomes are larger among poor and very poor families. This pattern holds across all outcomes except for BMI standard deviation from reference median. Richer families probably have the resources and are able to close the gap between twins that have higher birth weights and twins that have lower birth weight. Also, richer families usually contain high educated mothers who, as discussed above, have a higher tendency to close the health gap among their children.

\section{Endogenous Infant Mortality}

One of the potential confounding issues in examining the long term relationships is the sample selection bias. The fittest and healthiest newborns are more likely to survive the period of infancy and transit into childhood to be included in the sample. This fact concerns the results of this paper since we observe the anthropometric children in the sample up to age 5 when they already passed the transition period. If infants with lower birth endowment who could have revealed lower anthropometric outcomes during childhood die during infancy as a result of lower initial health, the estimated coefficients of equations 1 through 3 will be under-biased and understate the true effects. 
To explore this potential Endogeneity, Table 7 reports the results of a series of regressions from equations 1 to 3 where we replace the outcome with a dummy that equals one if the child is reported dead at the time of the interview and zero otherwise. We report the results of OLS in columns 1-3, the mother fixed effect in columns 4-5, and the results of the twin strategy in column 6 . The signs of all coefficients imply a protective effect of birth weight against the likelihood of infant death. An additional 100 grams of birth weight is associated with 2.2 and 4.4 basis points decrease in the likelihood of infant death in the full specifications of OLS and mother fixed-effect models (columns 3 and 5), respectively, equivalent to roughly 5 and 10 percent reduction from the mean. While the twin strategy also points to the negative effect and the magnitude is very close to that of OLS results it is imprecisely estimated. These results are in line with other studies that relate the infant mortality rates to birth weight and more generally health endowment at birth (Gage et al., 2013; Lau et al., 2013; McCormick, 1985). As a conclusion, the results of this section suggest that the marginal effects, reported and discussed in section 5 and 6 , are understating the true effects due to sample selection concerns. We need to use caution in interpreting the results as a lower-bond of the true effects.

\section{Conclusion}

Exploring the long term effects of health endowment at birth is important for policymakers to design optimal policy interventions. In this paper, we investigated the effect of birth weight on a series of anthropometric outcomes among children. On the contrary to the current literature, we explored this link in the case of developing countries. We attempted to solve the potential Endogeneity issues by applying mother fixed effect and twin fixed-effect strategies. Using individual-level data from 39 countries passing the years 1999-2018, we found that if the birth weight of infants at the bottom half of the sample was to converge to the mean birth weight (an increase of about 446 grams), the weight for age standard deviation from reference median, the height for age standard deviation from reference median, and the BMI standard deviation from reference median would have increased by $0.10,0.08$, and 0.08 units, respectively. These marginal effects are equivalent to an absolute change of 9.1,6.7, and 28.6 percent from the mean of their respective variables. While the effects become slightly smaller in twin fixed-effect models, they remain statistically and economically significant. In line with previous literature, the results suggest that improvements in birth weight results in improvements in anthropometric outcomes among children.

The results are heterogeneous by mothers' education and household wealth. The links between birth weight and children outcomes are stronger for low educated mothers and poorer households. The observed heterogeneity points to the ability and tendency of high-educated and wealthy families to compensate for the low health endowment of their weaker offspring. Besides, we discussed that there are protective 
effects of birth weight against infant mortality. This fact has the potential to underbias the estimates and suggests that the true effects are larger than the findings in this paper.

\section{References}

[1] Almond, D., Chay, K. Y., and Lee, D. S. (2005). The Costs of Low Birth Weight. The Quarterly Journal of Economics, 120(3), 1031-1083.

https://doi.org/10.1093/qje/120.3.1031

[2] Almond, D., and Currie, J. (2011). Killing me softly: The fetal origins hypothesis. Journal of Economic Perspectives, 25(3), 153-172. https://doi.org/10.1257/jep.25.3.153

[3] Almond, D., Hoynes, H. W., and Schanzenbach, D. W. (2011). Inside the war on poverty: The impact of food stamps on birth outcomes. Review of Economics and Statistics, 93(2), 387-403. https://doi.org/10.1162/REST_a_00089

[4] Bacallao, J., Amador, M., and Hermelo, M. (1996). The relationship of birth weight with height at 14 and with the growing process. Nutrition, 12(4), 250-254. https://doi.org/10.1016/S0899-9007(96)90851-5

[5] Behrman, J. R., and Rosenzweig, M. R. (2004). Returns to birth weight. In Review of Economics and Statistics (Vol. 86, Issue 2, pp. 586-601). https://doi.org/10.1162/003465304323031139

[6] Behrman, R. E., Butler, A. S., and others. (2007). Preterm birth: causes, consequences, and prevention.

[7] Bharadwaj, P., Bietenbeck, J., Lundborg, P., and Rooth, D. O. (2019). Birth weight and vulnerability to a macroeconomic crisis. Journal of Health Economics, 66, 136-144. https://doi.org/10.1016/j.jhealeco.2019.05.001

[8] Bharadwaj, P., Lundborg, P., and Rooth, D. O. (2018). Birth weight in the long run. Journal of Human Resources, 53(1), 189-231.

https://doi.org/10.3368/jhr.53.1.0715-7235R

[9] Black, S. E., Devereux, P. J., and Salvanes, K. G. (2007). From the cradle to the labor market? The effect of birth weight on adult outcomes. The Quarterly Journal of Economics, 122(1), 409-439. https://doi.org/10.1162/qjec.122.1.409

[10] Brinkman, H. J., Drukker, J. W., and Slot, B. (1988). Height and income: A new method for the estimation of historical national income series. Explorations in Economic History, 25(3), 227-264. https://doi.org/10.1016/00144983(88)90001-0

[11] Cole, N., and Currie, J. (1993). Welfare and child health: The link between AFDC participation and birth weight. American Economic Review, 83(4), 971-985. https://doi.org/10.2307/2117589

[12] Conley, D., Strully, K. W., and Bennett, N. G. (2006). Twin differences in birth weight: The effects of genotype and prenatal environment on neonatal and 
post-neonatal mortality. Economics and Human Biology, 4(2), 151-183. https://doi.org/10.1016/j.ehb.2005.12.001Currie, J., and Grogger, J. (2002). Medicaid expansions and welfare contractions: Offsetting effects on prenatal care and infant health? Journal of Health Economics, 21(2), 313-335. https://doi.org/10.1016/S0167-6296(01)00125-4

[13] Datta Gupta, N., Deding, M., and Lausten, M. (2013). The effect of low birth weight on height, weight and behavioral outcomes in the medium-run. Economics and Human Biology, 11(1), 42-55. https://doi.org/10.1016/j.ehb.2011.06.002

[14] Deaton, A., and Arora, R. (2009). Life at the top: The benefits of height. Economics and Human Biology, 7(2), 133-136. https://doi.org/10.1016/j.ehb.2009.06.001

[15] East, C. N. (2018). The Effect of Food Stamps on Children's Health: Evidence from Immigrants' Changing Eligibility. Journal of Human Resources, 09168197R2. https://doi.org/10.3368/jhr.55.3.0916-8197r2

[16] Figlio, D., Guryan, J., Karbownik, K., and Roth, J. (2014). The effects of poor neonatal health on children's cognitive development? American Economic Review, 104(12), 4205-4230. https://doi.org/10.1257/aer.104.12.3921

[17] Figlio, D., Hamersma, S., and Roth, J. (2009). Does prenatal WIC participation improve birth outcomes? New evidence from Florida. Journal of Public Economics, 93(1-2), 235-245. https://doi.org/10.1016/j.jpubeco.2008.08.003

[18] Frijters, P., Johnston, D. W., Shah, M., and Shields, M. A. (2013). Intrahousehold resource allocation: Do parents reduce or reinforce child ability gaps? Demography, 50(6), 2187-2208.

[19] Ga, Y., and Feng, L. (2012). Effects of federal nutrition program on birth outcomes. Atlantic Economic Journal, 40(1), 61-83. https://doi.org/10.1007/s11293-011-9294-y

[20] Gage, T. B., Fang, F., O’Neill, E., and DiRienzo, G. (2013). Maternal Education, Birth Weight, and Infant Mortality in the United States. Demography, 50(2), 615-635. https://doi.org/10.1007/s13524-012-0148-2

[21] Heger Boyle, E., King, M., and Sobek, M. (2020). IPUMS Demographic and Health Surveys. Version 8 [dataset]. Minneapolis, MN: IPUMS and ICF.2020. https://doi.org/https://doi.org/10.18128/D080.V8

[22] Hoynes, H., Miller, D., and Simon, D. (2015). Income, the earned income tax credit, and infant health. American Economic Journal: Economic Policy, 7(1), 172-211. https://doi.org/10.1257/pol.20120179

[23] Hoynes, H., Page, M., and Stevens, A. H. (2011). Can targeted transfers improve birth outcomes?. Evidence from the introduction of the WIC program. Journal of Public Economics, 95(7-8), 813-827. https://doi.org/10.1016/j.jpubeco.2010.12.006 
[24] Hoynes, H., Schanzenbach, D. W., and Almond, D. (2016). Long-run impacts of childhood access to the safety net. American Economic Review, 106(4), 903934. https://doi.org/10.1257/aer.20130375

[25] Kaestner, R., and Chan Lee, W. (2005). The effect of welfare reform on prenatal care and birth weight. Health Economics, 14(5), 497-511. https://doi.org/10.1002/hec.921

[26] Lau, C., Ambalavanan, N., Chakraborty, H., Wingate, M. S., and Carlo, W. A. (2013). Extremely low birth weight and infant mortality rates in the United States. Pediatrics, 131(5), 855-860. https://doi.org/10.1542/peds.20122471

[27] Leonard, J., and Mas, A. (2008). Welfare reform, time limits, and infant health. Journal of Health Economics, 27(6), 1551-1566.

https://doi.org/10.1016/j.jhealeco.2008.05.013 
[28] Maruyama, S., and Heinesen, E. (2020). Another look at returns to birth weight. Journal of Health Economics, 70, 102269. https://doi.org/10.1016/j.jhealeco.2019.102269

[29] McCormick, M. C. (1985). The Contribution of Low Birth Weight to Infant Mortality and Childhood Morbidity. New England Journal of Medicine, 312(2), 82-90. https://doi.org/10.1056/nejm198501103120204

[30] Meyer, H. E., and Selmer, R. (1999). Income, educational level and body height. Annals of Human Biology, 26(3), 219-227. https://doi.org/10.1080/030144699282723

[31] Miller, P., Mulvey, C., and Martin, N. (2005). Birth weight and schooling and earnings: Estimates from a sample of twins. Economics Letters, 86(3), 387392. https://doi.org/10.1016/j.econlet.2004.10.002

[32] NoghaniBehambari, H., Noghani, F., and Tavassoli, N. (2020a). Child support enforcement and child mortality. Available at SSRN 3668744.

[33] NoghaniBehambari, H., Noghani, F., and Tavassoli, N. (2020b). Early Life Income Shocks and Old-Age Cause-Specific Mortality. Economic Analysis, 53(2), 1-19.

[34] Noghanibehambari, H., Noghani, F., Tavassoli, N., and Toranji, M. (2020). Long-term effects of in utero exposure to 'The Year Without A Summer'. Available at SSRN 3668739.

[35] Noghanibehambari, H., and Salari, M. (2020). Health benefits of social insurance. Health Economics.

[36] Restrepo, B. J. (2016). Parental investment responses to a low birth weight outcome: Who compensates and who reinforces? Journal of Population Economics, 29(4), 969-989.

[37] Royer, H. (2009). Separated at girth: US twin estimates of the effects of birth weight. American Economic Journal: Applied Economics, 1(1), 49-85. https://doi.org/10.1257/app.1.1.49

[38] Sonchak, L. (2015). Medicaid reimbursement, prenatal care and infant health. Journal of Health Economics, 44, 10-24. https://doi.org/10.1016/j.jhealeco.2015.08.008

[39] Sonchak, L. (2016). The Impact of WIC on Birth Outcomes: New Evidence from South Carolina. Maternal and Child Health Journal, 20(7), 1518-1525. https://doi.org/10.1007/s10995-016-1951-y

[40] Sorensen, H. T., Sabroe, S., Rothman, K. J., Gillman, M., Steffensen, F. H., Fischer, P., and Serensen, T. I. A. (1999). Birth Weight and Length as 
Predictors for Adult Height. American Journal of Epidemiology, 149(8), 726729. https://doi.org/10.1093/oxfordjournals.aje.a009881

[41] Tavassoli, N., Noghanibehambari, H., Noghani, F., and Toranji, M. (2020). Upswing in Industrial Activity and Infant Mortality during Late 19th Century US. Journal of Environments, 6(1), 1-13.

https://doi.org/10.20448/journal.505.2020.61.1.13

[42] van den Berg, G. J., Doblhammer-Reiter, G., Christensen, K., den Berg, G. J., Doblhammer-Reiter, G., and Christensen, K. (2011). Being born under adverse economic conditions leads to a higher cardiovascular mortality rate later in life: Evidence based on individuals born at different stages of the business cycle. Demography, 48(2), 507-530. https://doi.org/10.1007/s13524-011-0021-8

[43] Wherry, L. R., Miller, S., Kaestner, R., and Meyer, B. D. (2018). Childhood medicaid coverage and later-life health care utilization. Review of Economics and Statistics, 100(2), 287-302. https://doi.org/10.1162/rest_a_00677

[44] Witherspoon, D. J., Wooding, S., Rogers, A. R., Marchani, E. E., Watkins, W. S., Batzer, M. A., and Jorde, L. B. (2007). Genetic similarities within and between human populations. Genetics, 176(1), 351-359. https://doi.org/10.1534/genetics.106.067355

Tables

Table 1 - Sample Statistics

\begin{tabular}{lll}
\hline Country & Observations & $\begin{array}{l}\text { Share in the Final } \\
\text { Sample (\%) }\end{array}$ \\
\hline Angola & 6,865 & 1.10 \\
Myanmar & 1,998 & 0.32 \\
Burundi & 14,653 & 2.34 \\
Cameroon & 10,591 & 1.69 \\
Chad & 1,845 & 0.29 \\
Congo Democratic & 17,711 & 2.83 \\
Republic & 27,010 & 4.32 \\
Benin & 5,346 & 0.85 \\
Ghana & 8,601 & 1.38 \\
Guinea & 207,316 & 33.14 \\
India & 4,106 & 0.66 \\
Cote d'Ivoire & 45,129 & 7.22 \\
Jordan & &
\end{tabular}




\begin{tabular}{lll} 
Kenya & 10,831 & 1.73 \\
Lesotho & 7,114 & 1.14 \\
Liberia & 2,282 & 0.36 \\
Madagascar & 6,972 & 1.11 \\
Malawi & 35,939 & 5.75 \\
Mali & 8,968 & 1.43 \\
Morocco & 2,726 & 0.44 \\
Mozambique & 10,773 & 1.72 \\
Namibia & 9,643 & 1.54 \\
Niger & 5,705 & 0.91 \\
Nigeria & 17,105 & 2.73 \\
Pakistan & 4,804 & 0.77 \\
Rwanda & 17,565 & 2.81 \\
Senegal & 29,558 & 4.73 \\
South Africa & 2,896 & 0.46 \\
Zimbabwe & 14,308 & 2.29 \\
Uganda & 18,288 & 2.92 \\
Egypt & 20,572 & 3.29 \\
Tanzania & 13,533 & 2.16 \\
Burkina Faso & 12,143 & 1.94 \\
Yemen & 1,329 & 0.21 \\
Zambia & 21,260 & 3.40 \\
\hline Total & 625,485 & 100.00 \\
\hline
\end{tabular}

Notes. The sample covers the years 1999-2018.

Table 2 - Summary Statistics

\begin{tabular}{|c|c|c|c|c|c|c|}
\hline & \multicolumn{3}{|c|}{ Full Sample } & \multicolumn{3}{|l|}{ Twins } \\
\hline & Mean & $S D$ & $\begin{array}{l}\text { Observat } \\
\text { ions }\end{array}$ & Mean & $S D$ & $\begin{array}{l}\text { Observat } \\
\text { ions }\end{array}$ \\
\hline $\begin{array}{l}\text { Birth } \\
\text { Weight }\end{array}$ & $\begin{array}{l}3063 . \\
3559\end{array}$ & $\begin{array}{l}701.6 \\
407\end{array}$ & 625,485 & $\begin{array}{l}2483.9 \\
533\end{array}$ & $\begin{array}{l}733.99 \\
371\end{array}$ & 17,548 \\
\hline $\begin{array}{l}\text { Child Sex } \\
\text { (female= } \\
\text { 1) }\end{array}$ & $\begin{array}{l}0.486 \\
1\end{array}$ & $\begin{array}{l}0.499 \\
8\end{array}$ & 625,485 & 0.5009 & 0.5000 & 17,548 \\
\hline $\begin{array}{l}\text { Birth } \\
\text { Year }\end{array}$ & $\begin{array}{l}2009 . \\
5854\end{array}$ & $\begin{array}{l}4.923 \\
0\end{array}$ & 625,485 & $\begin{array}{l}2009.0 \\
231\end{array}$ & 5.0773 & 17,548 \\
\hline $\begin{array}{l}\text { Children } \\
\text { Ever } \\
\text { Born }\end{array}$ & $\begin{array}{l}3.125 \\
1\end{array}$ & $\begin{array}{l}2.069 \\
3\end{array}$ & 625,485 & 4.6624 & 2.2801 & 17,548 \\
\hline $\begin{array}{l}\text { Househol } \\
\text { d Age }\end{array}$ & $\begin{array}{l}42.11 \\
86\end{array}$ & $\begin{array}{l}14.17 \\
30\end{array}$ & 613,503 & $\begin{array}{l}42.579 \\
5\end{array}$ & $\begin{array}{l}13.406 \\
0\end{array}$ & 17,006 \\
\hline
\end{tabular}




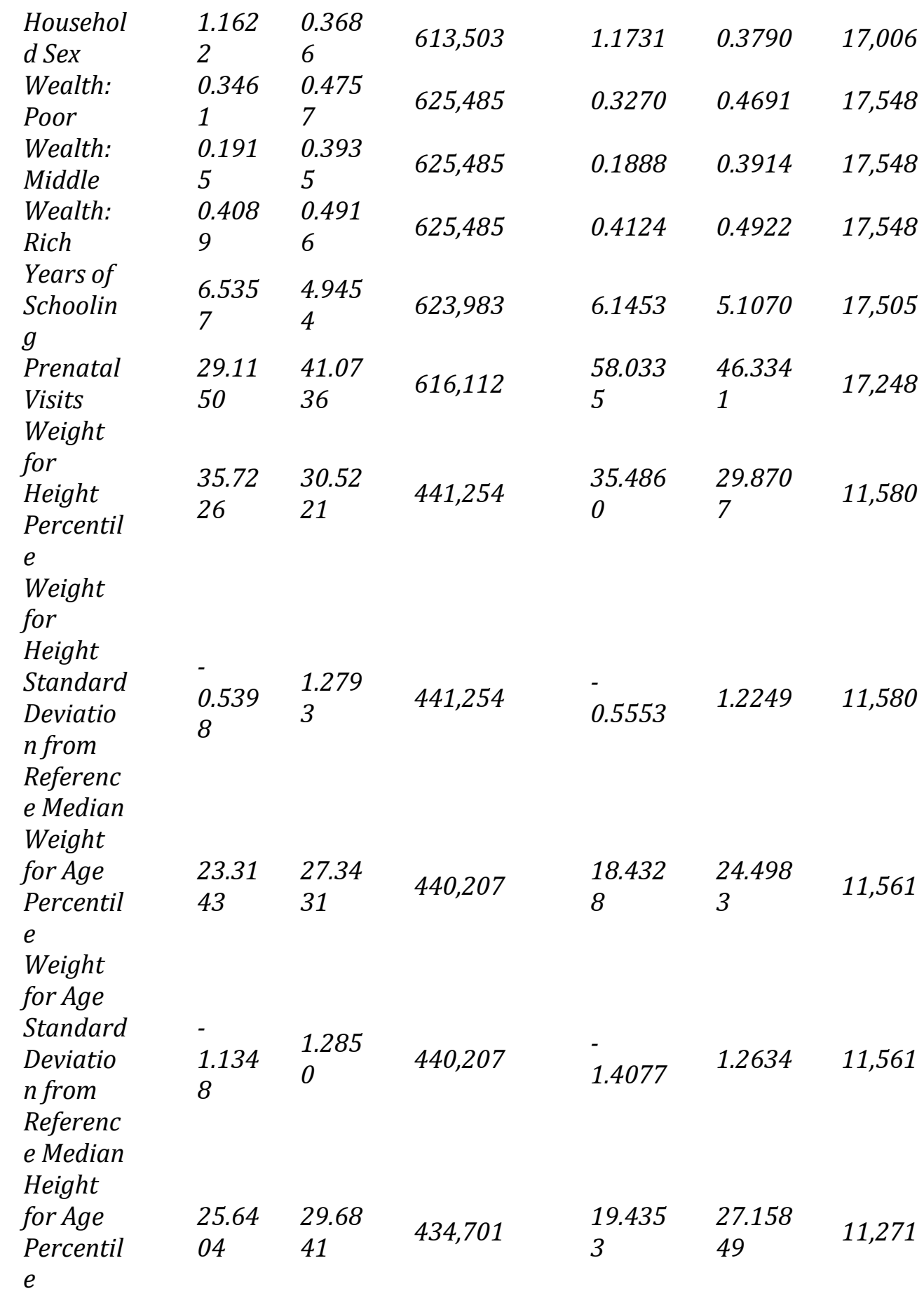



Height
for Age
Standard
Deviatio
$n$ from
$\begin{array}{ll}-1.124 & 1.542 \\ 0 & 9\end{array}$
442,153
1.5289
1.5901
11,614
Referenc
e Median
Body
Mass
Index
Standard
Deviatio
$n$ from

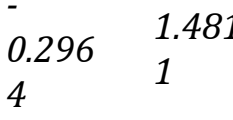
441,275
0.3396
1.4955
11,581
Referenc
e Median
Infant
$0.004 \quad 0.066$
Dead?
4
4
625,485
0.0332
0.1792
17,548

Notes. All anthropometric variables are based on the CDC (Centers for Disease Control and Prevention) standards for the reference median.

Table 3 - The Effect of Birth Weight on Anthropometric Outcomes of Children: OLS Models

\section{(1)}

Panel A. Outcome: Weight for Height Percentile

Birth Weight

$R^{2}$

Observations
$0.00528^{* * *}$

(0.00018)

0.180

441,054
(2)

$0.00534^{* * *}$

$0.00518^{* * *}$

(0.00020)

(0.00021)

0.190

416,443

0.185

427,505

(3)

Panel B. Outcome: Weight for Height Standard Deviation from the Reference Median

Birth Weight

$\begin{array}{lll}0.00021^{* * *} & 0.00022^{* * *} & 0.00020^{* * *} \\ (0.00009) & (0.00009) & (0.00008) \\ 0.165 & 0.169 & 0.173 \\ 441,054 & 427,505 & 416,443\end{array}$

$R^{2}$

Observations

441,054 
$R^{2}$

(0.00045)

(0.00049)

(0.00053)

Observations

0.178

0.187

0.208

440,007

426,492

415,439

Panel D. Outcome: Weight for Age Standard Deviation from the Reference Median Birth Weight

$0.00035^{* * *}$

$0.00035^{* * *}$

$0.00034^{* * *}$

$R^{2}$

(0.00001)

(0.00001)

(0.00001)

Observations

0.191

0.203

0.230

440,007

426,492

415,439

Panel E. Outcome: Height for Age Percentile

Birth Weight

$R^{2}$

Observations
$0.00558^{* * *}$

$(0.00020)$

0.089

434,501
$0.00563^{* * *}$

(0.00020)

0.101

428,438
$0.00532^{* * *}$

(0.0020)

0.124

417,385

Panel F. Outcome: Height for Age Standard Deviation from the Reference Median

Birth Weight

$0.00030^{* * *}$

$0.00031^{* * *}$

$0.00028^{* * *}$

$R^{2}$

$(0.00001)$

(0.00001)

(0.00001)

Observations

0.090

0.105

0.131

434,501

428,438

417,385

\section{Panel G. Outcome: Body Mass Index Standard Deviation from the Reference}

\section{Median}

Birth Weight

$\begin{array}{ll}0.00024^{* * *} & 0.00025^{* * *} \\ (0.00001) & (0.00001)\end{array}$

$R^{2}$

0.154

0.157

$0.00024^{* * *}$

Observations

441,073

427,466

(0.00001)

0.159

416,285

\begin{tabular}{llll}
\hline Country FE & Yes & Yes & Yes \\
Year FE & Yes & Yes & Yes \\
Birth Year by Birth Month FE & Yes & Yes & Yes \\
Sub-National Region FE & No & Yes & Yes \\
Sub-National Region by Year FE & No & No & Yes \\
Mother Characteristics Set 1 & No & Yes & Yes \\
Mother Characteristics Set 2 & No & No & Yes \\
\hline
\end{tabular}

Notes. Standard errors, reported in parentheses, are clustered on the sub-national region level. All regressions are weighted by person weights provided by DHS-IPUMS. Mother characteristics set 1 includes: a polynomial function of age, number of children ever born, a polynomial function of household age, household sex, and number of prenatal visits. Mother characteristics set 2 includes all covariates of set 1 in addition to 
mother's employment status, dummies for the type of occupation, household wealth quintiles, and education.

Table 4 - The Effect of Birth Weight on Anthropometric Outcomes of Children: Mother Fixed Effect Models
(1)

Panel A. Outcome: Weight for Height Percentile

Birth Weight $0.00519^{* * *}$ $0.00513^{* * *}$

$R^{2}$ $(0.00021)$ (0.00020)

Observations 0.681 0.689 441,054

Panel B. Outcome: Weight for Height Standard Deviation from the Reference Median

Birth Weight

$\begin{array}{ll}0.00020^{* * *} & 0.00020^{* * *} \\ (0.00009) & (0.00008) \\ 0.885 & 0.887 \\ 441,054 & 441,054\end{array}$

$R^{2}$

Observations

441,054

Panel C. Outcome: Weight for Age Percentile
$0.00528^{* * *}$
Birth Weight
$0.00598^{* * *}$
(0.00018)
$R^{2}$
(0.00019)
0.714
Observations
0.688
440,007

Panel D. Outcome: Weight for Age Standard Deviation from the Reference Median
Birth Weight
$0.00031^{* * *}$
$0.00030^{* * *}$
$R^{2}$
(0.00009)
(0.00008)
Observations
0.713
0.734
440,007
440,007

Panel E. Outcome: Height for Age Percentile
Birth Weight
$0.00425^{* * *}$
$0.00404^{* * *}$
$R^{2}$
$(0.00021)$
(0.00020)
Observations
0.649
0.674
434,501
434,501

Panel F. Outcome: Height for Age Standard Deviation from the Reference Median

Birth Weight

$0.00021^{* * *}$

$0.00022^{* * *}$ 

$R^{2}$
Observations
0.661
0.685
441,953
441,953

(0.00001)

(0.00001)

Panel G. Outcome: Body Mass Index Standard Deviation from the Reference Median

Birth Weight

$\begin{array}{ll}0.00024^{* * *} & 0.00025^{* * *} \\ (0.00001) & (0.00001) \\ 0.674 & 0.680 \\ 441,073 & 441,073\end{array}$

Observations

Yes

Mother FE

Yes

Yes

Country FE

No

Yes

Birth Year by Birth Month FE

No

Yes

Sub-National Region by Year FE

No

Yes

Notes. Standard errors, reported in parentheses, are clustered on the mother level.

All regressions are weighted by person weights provided by DHS-IPUMS.

Table 5 - The Effect of Birth Weight on Anthropometric Outcomes of Children: Twin Fixed Effect Models

\begin{tabular}{|c|c|c|c|c|c|c|c|}
\hline & $\begin{array}{l}\text { Weigh } \\
t \text { for } \\
\text { Heigh } \\
t \\
\text { Perce } \\
\text { ntile }\end{array}$ & $\begin{array}{l}\text { Weigh } \\
t \text { for } \\
\text { Heigh } \\
t \\
\text { Stand } \\
\text { ard } \\
\text { Devia } \\
\text { tion } \\
\text { from } \\
\text { Refere } \\
\text { nce } \\
\text { Media } \\
n\end{array}$ & $\begin{array}{l}\text { Weigh } \\
\text { t for } \\
\text { Age } \\
\text { Perce } \\
\text { ntile }\end{array}$ & $\begin{array}{l}\text { Weight } \\
\text { for Age } \\
\text { Standa } \\
\text { rd } \\
\text { Deviati } \\
\text { on } \\
\text { from } \\
\text { Refere } \\
\text { nce } \\
\text { Media } \\
n\end{array}$ & $\begin{array}{l}\text { Heigh } \\
\text { t for } \\
\text { Age } \\
\text { Perce } \\
\text { ntile }\end{array}$ & $\begin{array}{l}\text { Heigh } \\
\text { t for } \\
\text { Age } \\
\text { Stand } \\
\text { ard } \\
\text { Devia } \\
\text { tion } \\
\text { from } \\
\text { Refere } \\
\text { nce } \\
\text { Media } \\
n\end{array}$ & $\begin{array}{l}\text { Body } \\
\text { Mass } \\
\text { Index } \\
\text { Stand } \\
\text { ard } \\
\text { Devia } \\
\text { tion } \\
\text { from } \\
\text { Refere } \\
\text { nce } \\
\text { Media } \\
n\end{array}$ \\
\hline & (1) & (2) & (3) & (4) & (5) & (6) & (7) \\
\hline $\begin{array}{l}\text { Birth } \\
\text { Weight }\end{array}$ & $\begin{array}{l}0.003 \\
57^{* * *} \\
(0.001 \\
16)\end{array}$ & $\begin{array}{l}0.000 \\
14^{* * *} \\
(0.000 \\
04)\end{array}$ & $\begin{array}{l}0.004 \\
26^{* * *} \\
(0.000 \\
81)\end{array}$ & $\begin{array}{l}0.0002 \\
3^{* * *} \\
(0.000 \\
037)\end{array}$ & $\begin{array}{l}0.002 \\
49^{* * *} \\
(0.000 \\
61)\end{array}$ & $\begin{array}{l}0.000 \\
17^{* * *} \\
(0.000 \\
03)\end{array}$ & $\begin{array}{l}0.000 \\
19^{* * *} \\
(0.000 \\
05)\end{array}$ \\
\hline$R^{2}$ & 0.817 & 0.839 & 0.852 & 0.878 & 0.899 & 0.911 & 0.849 \\
\hline
\end{tabular}




\begin{tabular}{|c|c|c|c|c|c|c|c|}
\hline $\begin{array}{l}\text { Observa } \\
\text { tions }\end{array}$ & $\begin{array}{l}11,57 \\
4\end{array}$ & $\begin{array}{l}11,57 \\
4\end{array}$ & $\begin{array}{l}11,55 \\
5\end{array}$ & 11,555 & $\begin{array}{l}11,26 \\
5\end{array}$ & $\begin{array}{l}11,26 \\
5\end{array}$ & $\begin{array}{l}11,57 \\
5\end{array}$ \\
\hline Twin FE & Yes & Yes & Yes & Yes & Yes & Yes & Yes \\
\hline
\end{tabular}

Notes. Standard errors, reported in parentheses, are clustered on the twin level. All regressions are weighted by person weights provided by DHS-IPUMS.

Table 6 - Heterogeneity of the Effect of Birth Weight on Children Anthropometric Outcomes by Mother's Education and Household Wealth

\begin{tabular}{|c|c|c|c|c|c|c|c|}
\hline & $\begin{array}{l}\text { Weigh } \\
\text { tfor } \\
\text { Heigh } \\
t \\
\text { Perce } \\
\text { ntile }\end{array}$ & $\begin{array}{l}\text { Weigh } \\
\text { tfor } \\
\text { Heigh } \\
t \\
\text { Stand } \\
\text { ard } \\
\text { Deviat } \\
\text { ion } \\
\text { from } \\
\text { Refere } \\
\text { nce } \\
\text { Media } \\
n\end{array}$ & $\begin{array}{l}\text { Weigh } \\
\text { tfor } \\
\text { Age } \\
\text { Perce } \\
\text { ntile }\end{array}$ & $\begin{array}{l}\text { Weigh } \\
\text { tfor } \\
\text { Age } \\
\text { Stand } \\
\text { ard } \\
\text { Deviat } \\
\text { ion } \\
\text { from } \\
\text { Refere } \\
\text { nce } \\
\text { Media } \\
n\end{array}$ & $\begin{array}{l}\text { Heigh } \\
\text { t for } \\
\text { Age } \\
\text { Perce } \\
\text { ntile }\end{array}$ & $\begin{array}{l}\text { Height } \\
\text { for } \\
\text { Age } \\
\text { Stand } \\
\text { ard } \\
\text { Deviat } \\
\text { ion } \\
\text { from } \\
\text { Refere } \\
\text { nce } \\
\text { Media } \\
n\end{array}$ & $\begin{array}{l}\text { Body } \\
\text { Mass } \\
\text { Index } \\
\text { Stand } \\
\text { ard } \\
\text { Deviat } \\
\text { ion } \\
\text { from } \\
\text { Refere } \\
\text { nce } \\
\text { Media } \\
n\end{array}$ \\
\hline & (1) & $(2)$ & (3) & $(4)$ & (5) & (6) & (7) \\
\hline \multicolumn{8}{|c|}{ Panel A. Mother's Education $<$ Secondary } \\
\hline & 0.004 & 0.000 & 0.004 & 0.000 & 0.002 & 0.0001 & 0.000 \\
\hline Birth & $40^{* * *}$ & $14^{* * *}$ & $35^{* * *}$ & $23^{* * *}$ & $29^{* * *}$ & $6^{* * * *}$ & $18^{* * *}$ \\
\hline Weight & $\begin{array}{l}(0.001 \\
26)\end{array}$ & $\begin{array}{l}(0.000 \\
04)\end{array}$ & $\begin{array}{l}(0.000 \\
99)\end{array}$ & $\begin{array}{l}(0.000 \\
04)\end{array}$ & $\begin{array}{l}(0.000 \\
68)\end{array}$ & $\begin{array}{l}(0.000 \\
04)\end{array}$ & $\begin{array}{l}(0.000 \\
05)\end{array}$ \\
\hline$R^{2}$ & 0.810 & 0.842 & 0.835 & 0.965 & 0.886 & 0.899 & 0.846 \\
\hline $\begin{array}{l}\text { Observa } \\
\text { tions }\end{array}$ & 6,510 & 6,510 & 6,492 & 6,492 & 6,250 & 6,250 & 6,516 \\
\hline \multicolumn{8}{|c|}{ Panel B. Mother's Education $\geq$ Secondary } \\
\hline & 0.002 & 0.000 & 0.004 & 0.000 & 0.002 & 0.0001 & 0.000 \\
\hline Birth & 45 & $14^{*}$ & $16^{* * *}$ & $22^{* * *}$ & $18^{* *}$ & $5^{* * *}$ & $11^{* *}$ \\
\hline Weight & $\begin{array}{l}(0.001 \\
99)\end{array}$ & $\begin{array}{l}(0.000 \\
08)\end{array}$ & $\begin{array}{l}(0.001 \\
37)\end{array}$ & $\begin{array}{l}(0.000 \\
06)\end{array}$ & $\begin{array}{l}(0.001 \\
13)\end{array}$ & $\begin{array}{l}(0.000 \\
04)\end{array}$ & $\begin{array}{l}(0.000 \\
04)\end{array}$ \\
\hline$R^{2}$ & 0.825 & 0.842 & 0.854 & 0.881 & 0.898 & 0.911 & 0.851 \\
\hline $\begin{array}{l}\text { Observa } \\
\text { tions }\end{array}$ & 5,029 & 5,029 & 5,028 & 5,028 & 4,980 & 4,980 & 5,024 \\
\hline
\end{tabular}


Panel C. Household's Wealth: Very Poor, Poor

$\begin{array}{llllllll} & 0.003 & 0.000 & 0.005 & 0.000 & 0.002 & 0.0002 & 0.000 \\ \text { Birth } & 39 & 11 & 05^{* * *} & 24^{* * *} & 50^{* * *} & 3^{* * *} & 16 \\ \text { Weight } & (0.002 & (0.000 & (0.001 & (0.000 & (0.000 & (0.000 & (0.000 \\ & 53) & 08) & 65) & 07) & 93) & 05) & 10) \\ R^{2} & 0.829 & 0.850 & 0.872 & 0.895 & 0.903 & 0.914 & 0.862 \\ \text { Observa } & 3,719 & 3,719 & 3,714 & 3,714 & 3,734 & 3,734 & 3,708 \\ \text { tions } & & & & & & & \end{array}$

Panel D. Household's Wealth: Middle, Rich, very Rich

$\begin{array}{llllllll} & 0.003 & 0.000 & 0.003 & 0.000 & 0.002 & 0.0001 & 0.000 \\ \text { Birth } & 21^{* * *} & 10^{* * *} & 95^{* * *} & 22^{* * *} & 41^{* * *} & 4^{* * *} & 20^{* * *} \\ \text { Weight } & (0.001 & (0.000 & (0.001 & (0.000 & (0.000 & (0.000 & (0.000 \\ & 17) & 04) & 00) & 04) & 82) & 04) & 05) \\ R^{2} & 0.811 & 0.833 & 0.843 & 0.869 & 0.896 & 0.910 & 0.865 \\ \text { Observa } & 7,178 & 7,178 & 7,167 & 7,167 & 7,200 & 7,200 & 7,183 \\ \text { tions } & & & & & & & \end{array}$

\begin{tabular}{llllllll}
\hline Twin FE & Yes & Yes & Yes & Yes & Yes & Yes & Yes
\end{tabular}

Notes. Standard errors, reported in parentheses, are clustered on the twin level. All regressions are weighted by person weights provided by DHS-IPUMS.

Table 7 - Birth Weight and Child Mortality

\section{Outcome: Child is Dead $\times 100$}

OLS Model

(1)

(2)

(3)

$0.00018^{* * *}$

$0.00021^{* * *}$

$0.00022^{* * *}$

(0.00004)

(0.00006)

0.006

(0.00006)

624,919

0.035

0.036

603,564

579,530

$\begin{array}{lll}\text { No } & \text { No } & \text { No } \\ \text { No } & \text { No } & \text { No } \\ \text { Yes } & \text { Yes } & \text { Yes } \\ \text { Yes } & \text { Yes } & \text { Yes }\end{array}$

No

Yes

Yes
Mother Fixed Effect

Model
Twin

Fixed

Effect

Model

(6)

(4)

(5)

(6)

$\begin{array}{ll}0.00045^{* * *} & 0.00044^{* * *} \\ (0.00015) & (0.00014) \\ 0.686 & 0.687 \\ 624,919 & 624,919\end{array}$

$-0.00025$

(0.00073)

0.776

17,533

624,919

\section{$T$}

Mother FE

Country FE

Year FE

No

Yes

No

No
Yes

No

No

No 
Birth Year by

Birth Month

FE

Sub-National

Region FE

No

Yes

Yes

Yes

No

Yes

No

Sub-National

Region by Year

No

Yes

Yes

No

Yes

No

FE

Mother

Characteristics

No

No

Yes

No

Yes

No

Set 1

Mother

Characteristics

No

No

Yes

No

No

No

Set 2

Notes. Standard errors, reported in parentheses, are clustered on the sub-national region level for columns 1-3, mother level for columns 4-5, and twin level for column 6. All regressions are weighted by person weights provided by DHS-IPUMS. Mother characteristics set 1 includes: a polynomial function of age, number of children ever born, a polynomial function of household age, household sex, and number of prenatal visits. Mother characteristics set 2 includes all covariates of set 1 in addition to mother's employment status, dummies for the type of occupation, household wealth quintiles, and education. 